Sains Malaysiana 50(11)(2021): 3159-3169

http://doi.org/10.17576/jsm-2021-5011-01

\title{
Seasonal Occurrence, Distribution and Group Size of Irrawaddy Dolphins (Orcaella brevirostris) in the Bay of Brunei, Brunei Darussalam
}

(Kejadian Bermusim, Taburan dan Saiz Kumpulan Ikan Lumba-lumba Irrawaddy (Orcaella brevirostris) di Teluk Brunei, Brunei Darussalam)

\author{
Farah Dayana Haji Ismail, Nurlisa Azizul, Saifullah Arifin JaAmaN*, AZMi Marzuki Muda, Mohd Vol \\ Momin, Bohari AbDullah, Xuelei Zhang \& Hairul Masrini MuHAMad
}

\begin{abstract}
The uniqueness of the Bay of Brunei makes it an ideal place to be inhabited by Irrawaddy dolphins. However, the increasing potential impacts of anthropogenic factors and environmental changes on the dolphins are alarming. The objectives of this study were to determine the seasonal occurrence and distribution, and to estimate the group size of Irrawaddy dolphins in the Bay of Brunei. Surveys were conducted between January 2016 and April 2018. The total distance surveyed was 2,439.2 km in $189.13 \mathrm{~h}$ (survey effort =13,081.93 km.h). Forty-nine groups of Irrawaddy dolphins were recorded with a sighting rate of $0.37 \mathrm{per} 100 \mathrm{~km} . \mathrm{h}$. Thirteen of the groups were observed with calves. Overall, the group size ranged between 1 and 15 individuals with a mean of 4.5 individuals $(S D=3.3)$. There was no statistical significance in the number of dolphin sightings between four different monsoon seasons (Northeast, Southwest, April Inter-monsoon, and October Inter-monsoon) $\left(\chi^{2}=5.66, d f=3, p>0.05\right)$. The number of sightings and number of individuals suggest that Irrawaddy dolphins are residents of the Bay of Brunei and are in need of a conservation management plan.
\end{abstract}

Keywords: Bay of Brunei; distribution; group size; Irrawaddy dolphin; occurrence

ABSTRAK

Keunikan Teluk Brunei menjadikan ia sebagai tempat yang ideal untuk didiami oleh ikan lumba-lumba Irrawaddy. Kesan peningkatan faktor antropogen dan perubahan alam sekitar terhadap ikan lumba-lumba bagaimanapun membimbangkan. Objektif kajian ini adalah untuk menentukan corak kehadiran, taburan dan menganggarkan saiz kumpulan ikan lumba-lumba Irrawaddy di Teluk Brunei. Tinjauan telah dijalankan dari Januari 2016 hingga April 2018. Jumlah jarak yang ditinjau ialah 2,439.2 km pada 189.13 jam (usaha tinjauan =13,081.93 km.j) dengan kadar penglihatan 0.37 setiap $100 \mathrm{~km} . j$. Jumlah keseluruhan penemuan yang direkodkan adalah 49 dan telah didapati bahawa 13 daripada penemuan tersebut mempunyai kehadiran ikan lumba-lumba kecil. Secara keseluruhannya, saiz kumpulan adalah antara 1 hingga 15 individu dengan purata 4.5 individu $(S D=3.3)$. Bilangan penemuan ikan lumba-lumba di antara keempat-empat musim monsun (Monsun Timur Laut, Monsun Barat Daya, peralihan monsun April dan peralihan monsun Oktober adalah secara statistiknya tidak signifikan $\left(\chi^{2}=5.66, d f=3, p>0.05\right)$. Jumlah penemuan dan bilangan individu menunjukkan bahawa ikan lumba-lumba Irrawaddy menghuni kawasan tersebut dan pelan pengurusan pemuliharaan spesies merupakan keperluan di Teluk Brunei.

Kata kunci: Ikan lumba-lumba Irrawaddy; penemuan; saiz kumpulan; taburan; teluk Brunei

\section{INTRODUCTION}

Cetacean species are widely distributed in marine environments. Of the world's ca. 90 cetacean species, three can be found only in freshwater habitat (Amazon river dolphin Inia geoffrensis, South Asian river dolphin
Platanista gangetica and Yangtze river dolphin Lipotes vexillifer) and another four species inhabit both coastal and freshwater environment (Yangtze finless porpoise, Neophocaena asiaorientalis ssp. asiaorientalis, Irrawaddy dolphin, Orcaella brevirostris and tucuxi Sotalia 
fluviatilis and S. guianensis) (Krützen et al. 2018). Irrawaddy dolphins (Orcaella brevirostris) were first mentioned in the literature of Owen (1866). It was described that the species was found in 1852 at the mouth of the Vishakhapatnam (previous known as Vizagapatam) river along the east coast of India (Stacey \& Leatherwood 1997).

Irrawaddy dolphins are patchily distributed in coastal, brackish and fresh waters in the tropical and sub-tropical Indo-Pacific (Jackson-Ricketts 2016; Jefferson et al. 2008). They have been recorded in rivers (Bali et al. 2017; Jefferson et al. 2008; Smith 2004; Smith \& Beasley 2004a, 2004b), lakes (Beasley et al. 2003, 2002; Pattnaik et al. 2007) and coastal waters (Hines et al. 2015; Minton et al. 2017; Perrin et al. 1996; Pilleri \& Gihr 1974; Smith et al. 1997; Sutaria \& Marsh 2011) across Southeast Asia. Generally, the status of coastal Irrawaddy dolphins reported by the IUCN Red List of Threatened Species was Endangered (Rodríguez-Vargas et al. 2019) and river Irrawaddy dolphin's status was Critically Endangered due small population size $(<50$ mature individual) (Minton et al. 2017). Their coastal and freshwater distribution exposes them to numerous anthropogenic threats such as accidental bycatch in fisheries, entangle by the fishing net and habitat loss (Junchompoo et al. 2013), over fishing (Silvestre \& Garces 2004), boat disturbance, i.e. noise (JacksonRicketts 2016) and intense shipping and maritime activities (Lim 1992).

The Bay of Brunei is one of the areas that are inhabited by the Irrawaddy dolphins in Asia. In the Bay of Brunei, whilst Irrawaddy dolphins have been sighted in Brunei waters (Elkin 1992; Gibson-Hill 1950, 1949; Jiang et al. 2020; Stacey \& Letherwood 1997; Weber 1923), much of the literature for the region focuses on the species in Malaysian waters. Past studies on Irrawaddy dolphin in Malaysia side of the bay have been mostly investigated on their distribution, population, abundance, and acoustics (Jaaman et al. 2016; Jiang et al. 2020, 2019; Mahmud 2016; Mahmud et al. 2018a, 2018b; Muhamad et al. 2020, 2018). Species presence in the bay may be due to favorable environmental conditions. The bay receives fresh water input from the rivers of Sungai (Sg.) Batang, Sg. Bengkulit, Sg. Punang, Sg. Awat-awat, Sg. Sundar, and Sg. Trusan. The bay is predominantly bordered by mangrove forest, which is known to support high diversity of marine species (i.e. fish and shrimp) (Ministry of Industry and Primary Resources 2015). In addition, the area is secluded from strong winds and rough seas, providing shelter for nurturing calves. At present, information on the distribution of the Irrawaddy dolphins in the bay is rudimentary and inadequately documented (Jaaman \& Bali 2011). Missing baseline data on Brunei's Irrawaddy dolphins is required as it may affect the conservation of the species across the entire bay.

The well documented information is required to support the development of effective conservation management plans of Irrawaddy dolphin. Thus, the current study aims to determine the occurrence, distribution, and the group size of Irrawaddy dolphins in the Brunei waters of the Bay of Brunei during Northeast monsoon (November-March), April Inter-monsoon (April), Southwest monsoon (May-September), October Inter-monsoon (October).

\section{Materials AND METHODS}

\section{STUDY SITE}

The surveys were conducted in the Bay of Brunei, Brunei Darussalam, located at the north-western coast of the Borneo Island and east of Bandar Seri Begawan $\left(5^{\circ} 00^{\prime} 43.44\right.$ " N , 115 17'26.66" E). The bay is split into four jurisdictions, Malaysian Sarawak, Sabah and Federal Territory of Labuan, and Brunei (Figure 1). The unique ecosystems of the bay support several ecosystems, including mangrove forests, seagrass beds, coral reefs, and mudflats.

Annually, the area receives a substantial amount of rain and has a high humidity level $(70 \%$ to $90 \%)$ with daily temperature between $24{ }^{\circ} \mathrm{C}-30{ }^{\circ} \mathrm{C}$. According to Tisen (2011), the bay is affected by two types of monsoon seasons which are Northeast (November - March) and Southwest (May - September). The transitions between these two monsoons occur in April and October. Major periods of heavy rain occur during the Northeast monsoon. It is the rainstorm climate frameworks, in conjunction with cool air episodes from Siberia, which create downpours that continue for several days. In contrast, during the Southwest monsoon, the weather is hotter and drier. The winds blow toward the south-west at speeds of less than 15 knots. This condition may also lead to the formation of haze in the land area.

\section{MATERIALS AND METHODS}

Comprehensive boat-based surveys were conducted in the Bay of Brunei for two to five days every four months between January 2016 and April 2018, using standard direct count method. Four different routes were designed to ensure the entire area was covered thoroughly, covering mangrove, riverine, and coastal areas. Survey routes followed modified lines transect selected based on the 


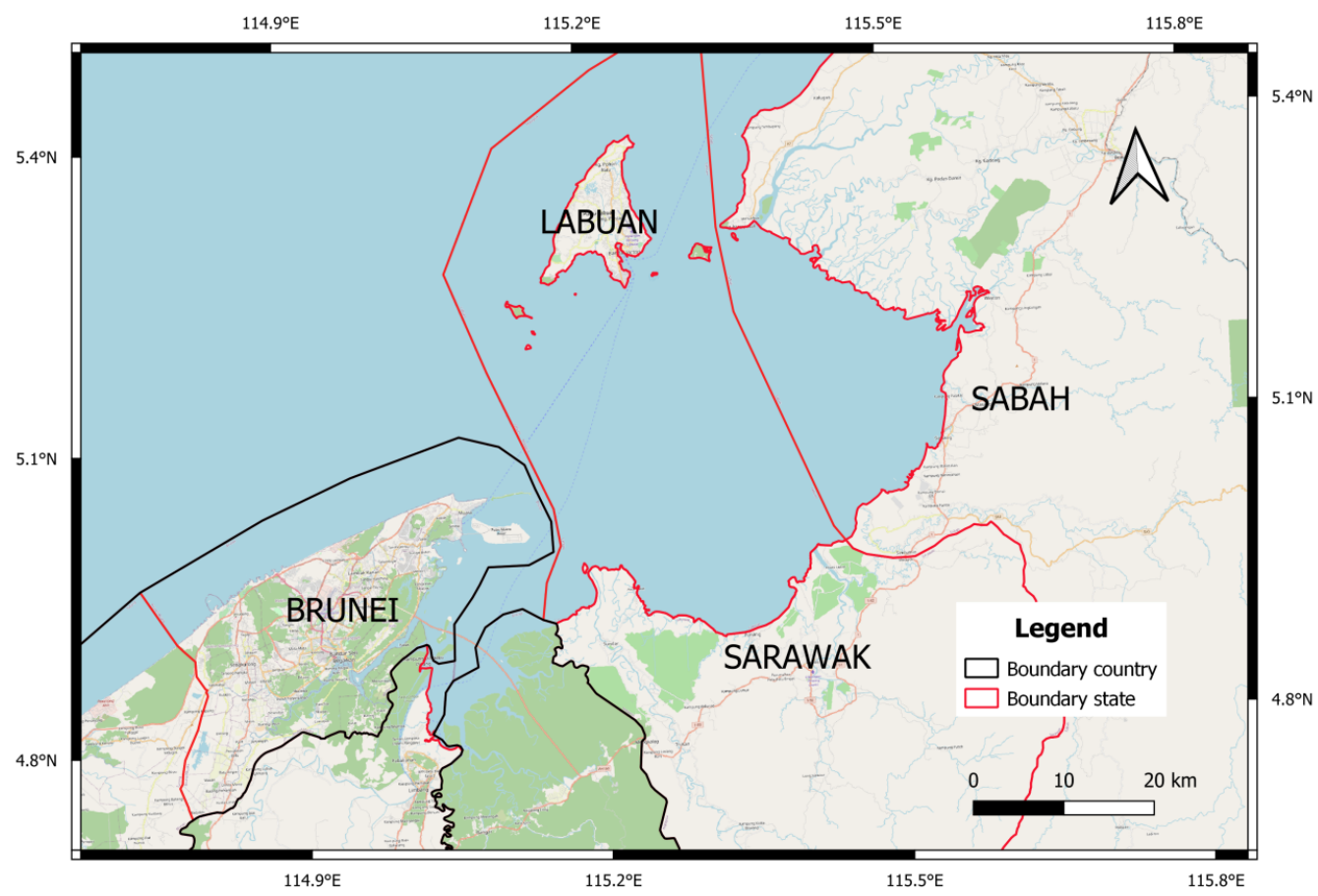

FIGURE 1. Map of the Bay of Brunei and its four jurisdictions (Labuan, Sabah, Sarawak, Brunei)

topography of the area. For this study, the transect lines were designed within less than five kilometers from the shore. This is because according to Atkin et al. (2004), the dolphins preferred to utilize the area within two kilometers of the shore extensively. However, when modifying the survey routes, the limitation factors such as depth, tides, security and the size or endurance of the boat were considered and it prompted the transect line to not be placed randomly.

The data collected covered all the monsoon seasons (Northeast monsoon, Southwest monsoon, April Intermonsoon, October Inter-monsoon). The surveys were conducted only during daytime between $0800 \mathrm{~h}$ and $1700 \mathrm{~h}$, in sea conditions no more than Beaufort 3. The speed of the survey boat was maintained between $10 \mathrm{~km}$ per $h$ and $15 \mathrm{~km}$ per h. According to Weir (2009), the speed of the boat should not exceed $15 \mathrm{~km}$ per hour, to ensure the observers were able to distinguish their surroundings noticeably.

During surveys, there were a minimum of three observers searching for dolphins. One observer observed the port side and one observed the starboard side, both used naked eyes and occasionally scanned the area with $\mathrm{NIKON}^{\circ}$ marine binoculars $7 \times 50 \mathrm{WP}$ Compass from the bow to the stern $\left(180^{\circ}\right)$. The third observer used the same technique to observe $90^{\circ}$ on either side of the bow and acted as a data recorder.

When dolphins were spotted, the effort was adjourned and all the observers were notified to the dolphin's sighting position. The boat approached the dolphins at slower and constant speed to avoid any disturbance towards dolphin's behaviour and direction. The GPS position of the dolphins and time were immediately recorded using a GARMIN GPSMAP 78s handheld Global Positioning System (GPS). The fundamental data on the number of individuals in the group, the presence of mother and calf pairs, time and Beaufort Sea state were recorded. A distance of between $20 \mathrm{~m}$ and $50 \mathrm{~m}$ from the dolphins was maintained and they were followed until they disappeared. All navigational and sighting data collected during the surveys were transferred and saved in a Microsoft ${ }^{\circledR}$ Excel database. The seasonal distribution maps were generated by using the GPS points transferred into QGIS 3.16 Hannover Software.

The survey effort was determined by multiplying the distance surveyed by the time surveyed (1). Wang et al. (2001) stated that the analysed data should be standardized to both distance and time used (km.h). 
The standardization to time alone may not accurately represent amount of area surveyed if the time spent for observing the animals or the boat's speed for searching were different. The same concept was applied to distance as it would not represent the amount of effort per unit of distance. The modification for differences in effort was using the same principle as catch per unit effort (CPUE).

Survey effort $=$ Distance surveyed $(\mathrm{km}) \times$ time surveyed (h)

The occurrence of Irrawaddy dolphins was determined by calculating a sighting rate. Sighting rates were calculated as number of sighting per unit effort (2). The data were presented according to monsoon seasons.

$$
\text { Sighting rate }=\frac{\text { Total number of sighting }}{\text { Total survey effort }(\mathrm{km} . \mathrm{h})} \times 100
$$

Chi-square $\left(\chi^{2}\right)$ test (using IBM SPSS Statistics 26 for windows software) was used to find the relationship between the occurrence and the monsoon seasons. The mean group size of Irrawaddy dolphins was determined from the best count of individuals in each group sighted.

\section{RESULTS}

\section{SURVEY EFFORT}

Overall, 36 days were spent conducting boat survey in the Bay of Brunei from January 2016 to April 2018. The total distance covered was 2,439.2 km during $189.13 \mathrm{~h}$ of 'on effort' searching (Figure 2). The total daily effort (the total of surveyed distance and time summed over all trip) was $13,081.93 \mathrm{~km} . \mathrm{h}$ and all the effort were made in Beaufort Sea state $<4$. The number of sightings recorded between January 2016 and April 2018 was 49 .

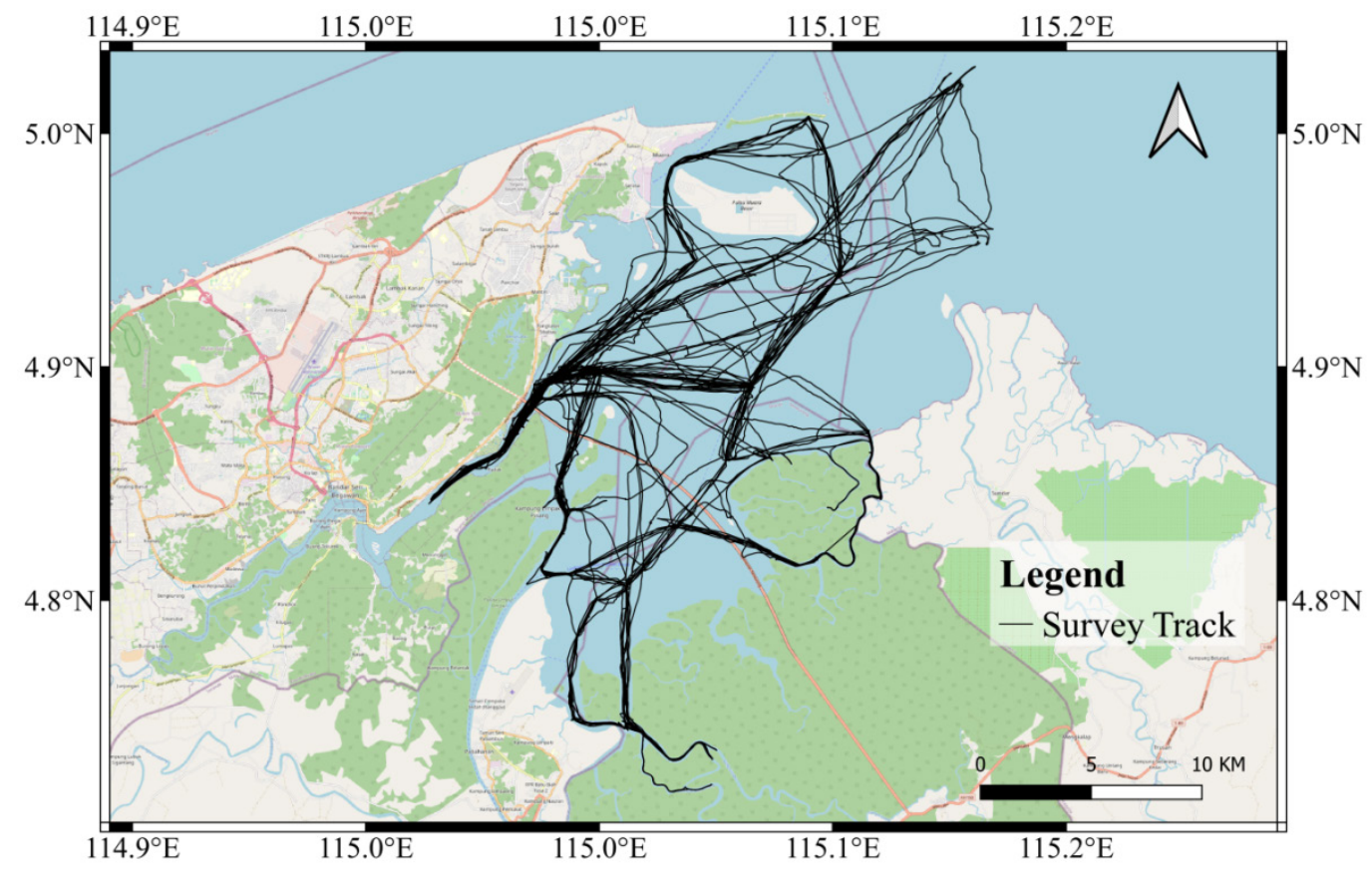

FIGURE 2. Map of survey track lines followed from between January 2016 and April 2018

\section{SIGHTING DISTRIBUTION AND RATE}

Sightings of Irrawaddy dolphins were made during all four seasons (Table 1) and were not distributed evenly between each season (Figure 3 ). The sightings of Irrawaddy dolphins in the river area mostly reported during Southwest monsoon and no sighting was reported in this area during Northeast monsoon. During Northeast monsoon and October Inter-monsoon Irrawaddy dolphins were commonly found in the middle area of the bay. The sightings were concentrated near to Pulau Cermin and Pulau Pelumpung during April Inter-monsoon. 
Overall, the sighting rate reported from January 2016 to April 2018 was 0.37 per 100 km.h. April Intermonsoon recorded the highest sighting rate which was 0.59 sightings per $100 \mathrm{~km}$.h of survey effort. The lowest sighting rate was during the Northeast monsoon where the sighting rate was only 0.25 per $100 \mathrm{~km}$.h of survey effort, making the number of sightings in the April Inter- monsoon double compared to the Northeast monsoon. Southeast monsoon and October Inter-monsoon shared the same number of sightings which were 11 with a sighting rate of 0.37 and 0.32 per $100 \mathrm{~km} . \mathrm{h}$ of survey effort, respectively. The observed and expected number of dolphins sighted during the four monsoon seasons were not statistically different $\left(\chi^{2}=5.66, \mathrm{df}=3, \mathrm{p}=0.129\right)$.

TABLE 1. Summary of boat surveys conducted in the Bay of Brunei between January 2016 and April 2018

\begin{tabular}{|c|c|c|c|c|c|c|c|c|}
\hline \multirow{2}{*}{ Seasons } & \multirow{2}{*}{$\begin{array}{c}\text { Day } \\
\text { surveyed }\end{array}$} & \multirow{2}{*}{$\begin{array}{l}\text { Distance } \\
\quad(\mathrm{km})\end{array}$} & \multirow{2}{*}{$\underset{(\mathrm{h})}{\text { Time }}$} & \multirow{2}{*}{$\begin{array}{l}\text { Survey } \\
\text { effort } \\
(\mathrm{km} . \mathrm{h})\end{array}$} & \multicolumn{3}{|c|}{$\begin{array}{c}\text { No. of } \\
\text { sighting }\end{array}$} & \multirow{2}{*}{$\begin{array}{l}\text { Sighting rate } \\
(100 \mathrm{~km} . \mathrm{h})\end{array}$} \\
\hline & & & & & 2016 & 2017 & 2018 & \\
\hline $\begin{array}{l}\text { Northeast } \\
\text { Monsoon }\end{array}$ & 10 & 691.9 & 51.13 & 3610.39 & 1 & 3 & 5 & 0.25 \\
\hline $\begin{array}{l}\text { April } \\
\text { Inter- } \\
\text { Monsoon }\end{array}$ & 10 & 656.2 & 45.1 & 3036.24 & 2 & 5 & 11 & 0.59 \\
\hline $\begin{array}{l}\text { Southwest } \\
\text { Monsoon }\end{array}$ & 7 & 504.4 & 41.06 & 2990.57 & 4 & 7 & - & 0.37 \\
\hline $\begin{array}{l}\text { October } \\
\text { Inter- } \\
\text { Monsoon }\end{array}$ & 9 & 586.7 & 51.84 & 3444.73 & 6 & 5 & - & 0.32 \\
\hline Total & 36 & 2439.2 & 189.13 & 13081.93 & 13 & 20 & 16 & \\
\hline
\end{tabular}

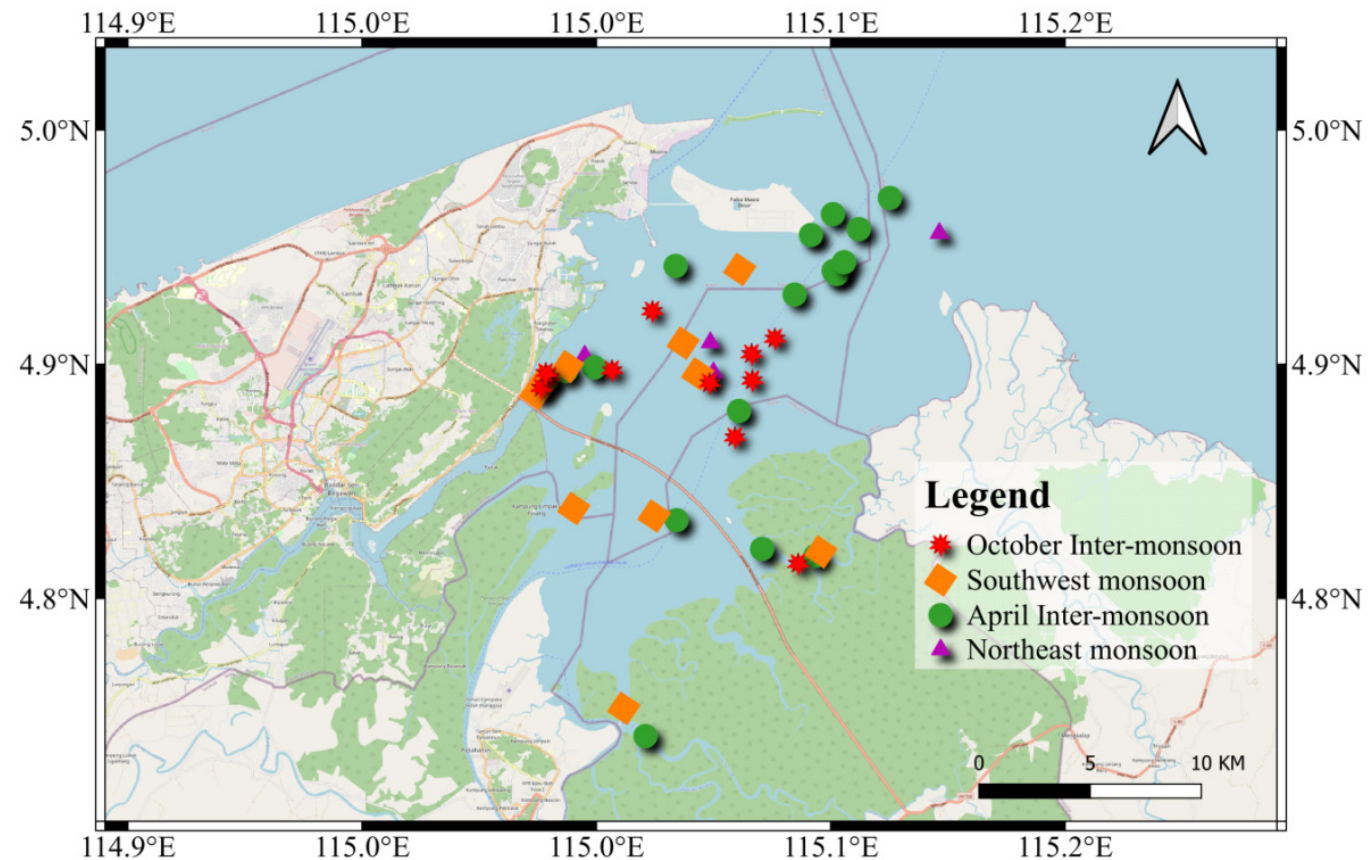

FIGURE 3. Sightings of Irrawaddy dolphins during Northeast monsoon $(\mathrm{n}=9)$, April Inter-monsoon $(\mathrm{n}=18)$, Southwest monsoon $(\mathrm{n}=11)$, and October Inter-monsoon $(\mathrm{n}=11)$ 
GROUP SIZE

Throughout the survey period, Irrawaddy dolphins were the only species of cetacean recorded in Bruneian waters making the overall mean of the group size 4.5 (SD
$= \pm 3.3$ ). As the total number of sightings was 49 , only $13(26.53 \%)$ sightings were recorded with association of mother and calf. The group size ranged between 1 and 15 individuals (Table 2).

TABLE 2. Number of sightings, calf presence and group size (mean with standard deviation (SD), and range) of Irrawaddy dolphins recorded during boat surveys in the waters of Brunei

\begin{tabular}{|c|c|c|c|c|c|c|}
\hline \multirow{2}{*}{ Seasons } & \multirow{2}{*}{$\begin{array}{l}\text { Num. of sighting } \\
\text { (\% of total) }\end{array}$} & \multirow{2}{*}{$\begin{array}{l}\text { Sighting rate } \\
\text { (Per } 100 \mathrm{~km} . \mathrm{h})\end{array}$} & \multirow{2}{*}{$\begin{array}{l}\text { Num. of } \\
\text { groups with } \\
\text { calf }\end{array}$} & \multirow{2}{*}{$\begin{array}{c}\text { Num. of } \\
\text { individual } \\
\text { (\% of total) }\end{array}$} & \multicolumn{2}{|c|}{ Group size } \\
\hline & & & & & Mean & Range \\
\hline Northeast monsoon & $\begin{array}{c}9 \\
(18.3 \%)\end{array}$ & 0.25 & 6 & $\begin{array}{c}62 \\
(28.2 \%)\end{array}$ & $6.9 \pm \mathrm{SD}=4.2$ & $1-15$ \\
\hline $\begin{array}{c}\text { April } \\
\text { Inter-monsoon }\end{array}$ & $\begin{array}{c}18 \\
(36.7 \%)\end{array}$ & 0.59 & 3 & $\begin{array}{c}88 \\
(40.0 \%)\end{array}$ & $4.9 \pm \mathrm{SD}=10.2$ & $1-15$ \\
\hline Southwest monsoon & $\begin{array}{c}11 \\
(22.5 \%)\end{array}$ & 0.37 & 3 & $\begin{array}{c}33 \\
(15.0 \%)\end{array}$ & $3.0 \pm \mathrm{SD}=1.5$ & $1-6$ \\
\hline $\begin{array}{c}\text { October } \\
\text { Inter-monsoon }\end{array}$ & $\begin{array}{c}11 \\
(22.4 \%)\end{array}$ & 0.32 & 1 & $\begin{array}{c}37 \\
(16.8 \%)\end{array}$ & $3.4 \pm \mathrm{SD}=1.6$ & $1-6$ \\
\hline Total & 49 & & 13 & & $4.5 \pm \mathrm{SD}=3.3$ & $1-15$ \\
\hline
\end{tabular}

\section{DISCUSSION}

The sighting rate of the Bay of Brunei, Brunei Darussalam was 0.37 per $100 \mathrm{~km} . \mathrm{h}$. It is relatively high compared to the sighting rate of the adjacent area where according to Jaaman et al. (2016) the sighting rate in the Bay of Brunei, Malaysia was 0.21 per $100 \mathrm{~km} . \mathrm{h}$. Statistically, the seasonal study of Irrawaddy dolphins showed that there was no significant difference between seasons by comparing the number of sightings per hour of survey efforts. Thus, it indicates that the occurrence can happen throughout the entire year (Figure 4). The same results occurred in Banten bay, Indonesia (Khalifa et al. 2014), the Bay of Brunei, Malaysia (Mahmud 2016), and Kep Archipelago, Cambodia (Tubbs et al. 2020).

The Bay of Brunei is mainly surrounded by the mangrove forest and receives a substantial amount of freshwater input. Prey may be provided by the extensive mangrove forests which provide important breeding grounds for many fish species. Irrawaddy dolphins have been found to feed on several species of estuarine and demersal fishes (Baird \& Mounsouphom 1997; Barros et al. 2004; Jefferson 2000; Jefferson \& Hung 2004; Marsh et al. 1998; Ross 2002). The movements of this highly mobile dolphin species may have been influenced by the movement of the preferred prey. In addition, the records of Irrawaddy dolphins in areas where freshwater and saltwater mix, may be the result of prey aggregation in these areas. Baird and Mounsouphom (1994) had mentioned that the dolphin in Mekong River was less sighted in the study area during high water season as the dolphins followed the prey species to the larger tributaries. For other small coastal species, there was a study of IndoPacific Humpback dolphins in Xiamen Bay, China showed that the seasonal changes affected the availability of prey resources (Wang et al. 2016). During Northeast monsoon, the prey's distributions were widely dispersed away from the coast while they were amassed closer to the river during Southwest monsoon (Wang et al. 2016).

The variation in freshwater input due to seasonal variation in rainfall may also affect the seasonal sighting rate. The study on the impact of flood event on dolphin occupancy conducted by Fury and Harrison (2011) showed 


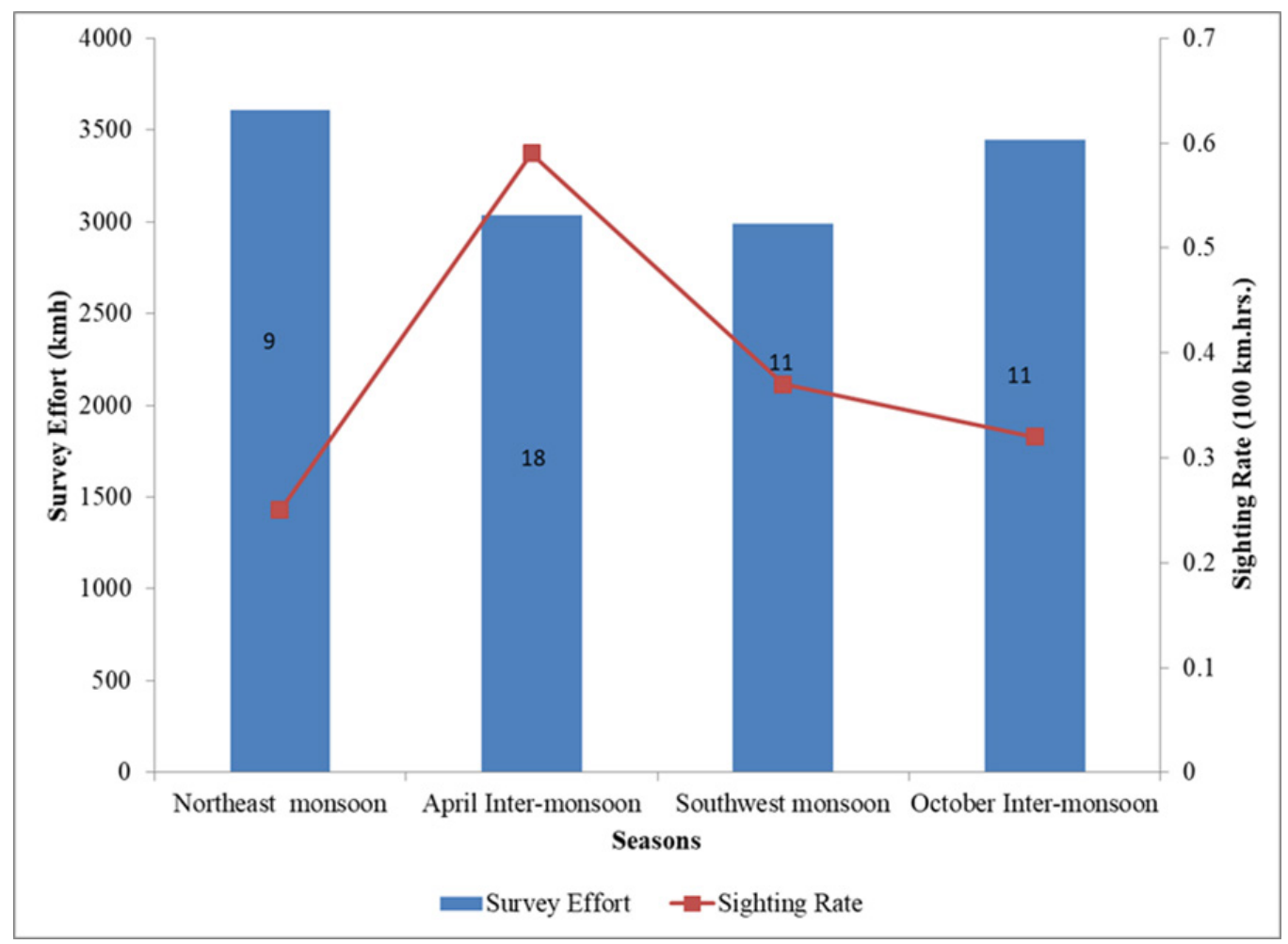

FIGURE 4. Sighting rate (number of sightings per hour effort) and survey effort of Irrawaddy dolphins in the Bay of Brunei during the four monsoon seasons

that during Northeast monsoon (wet season) the IndoPacific bottlenose dolphins (Tursiops aduncus) tend to move further away from the river mouth. Possibly, the records of Irrawaddy dolphins in the Bay of Brunei were affected by the same factor as only $33 \%$ of dolphins were recorded to be closer with the main rivers during Northeast monsoon.

According to Hashim and Jaaman (2011) and Stacey and Hvenegaard (2002), Irrawaddy dolphins show high sensitivity to noise pollutions such as roaring sounds from boats and ship engines, excessive ship and boat traffic, and coastal construction work. Based on the observation, all those activities were occurred in this area. During the time of the study, Temburong Bridge was being constructed along the bay, causing noise pollution. At early stage of the construction process there were a lot of piling events, yet Irrawaddy dolphins were still sighted and the numbers of sightings were increase over the years passes except during October Inter-monsoon (Table 2). There were records of Irrawaddy dolphin feeding and socializing near to the piling activity area. They went deep dive and had a quick surfacing to breath when the pilling activity were carried out or when the speed boat passing through the area. They also had positive interaction with the fishermen as they were found to swim towards fishermen boats and surfaced behind the trawler to feed on the fish caught in the net. $22 \%$ of occurrences were recorded near Pulau Cermin, which is located approximately $800 \mathrm{~m}$ from the bridge, less than $1000 \mathrm{~m}$ from the shore and $1500 \mathrm{~m}$ from Kampung Ayer (water village). It shows that the dolphins have positively adapted to the new environment. Irrawaddy dolphins may adapt to this disturbance as they have done in other locations for example by doing deep diving, decrease surfacing time for breathing as they have in the Mekong River (Stacey \& Hvenegaard 2002) and changing the swimming direction when they encountered container barged in the Mahakam river (Kreb et al. 2007).

Living in a group provides some advantages to the dolphins such as increased foraging opportunity, predator avoidance efficiency, and access to breeding opportunities (Stacey \& Hvenegaard 2002). The mean group size of Irrawaddy dolphins in the Bay of Brunei, Brunei Darussalam found during this study was 4.5 (SD $=3.3$, range $1-15)$. In the current study, only $13(26.5 \%)$ 
of the 49 groups contained calves. Whereas, Jaaman et al. (2016) reported more than $50 \%$ of Irrawaddy dolphin occurrences in Malaysia's Bay of Brunei to have calves present, and Mahmud (2016) stated the maximum of two calves were observed in large sized group, while zero to one individual can be sighted in small and medium group size in the Bay of Brunei, Malaysia.

Comparatively, Jaaman et al. (2016) and Mahmud (2016) found mean group sizes to be 7.6 $(\mathrm{SD}=7.36$, range $1-35)$ and $6(\mathrm{SE}=0.66$, range $1-18)$, respectively, in Malaysia's dolphins Bay of Brunei. Referring to Kuit et al. (2019), the mean group size of coastal Irrawaddy dolphins recorded in Matang, Perak was 6.4 individuals (S.E. = 0.3 , range $=1-32, n=253$ ) and most of the sighting were made while they were foraging. The same author has stated that $19 \%$ of the sightings were recorded with more and equal than 10 individuals. Based on 95 sightings made in Trat Bay, Trat Province, Thailand, it showed the mean group size was $4.94 \pm 4.9$ and the calves were usually been sighted between December and February (Junchompoo et al. 2013). The group size reported in Trat bay was various depends on the dolphins' behavior such as foraging for cephalopods (7.2 individual dolphins, SD $\pm 4.2, \mathrm{n}=12$, range $=2$ to 18$)$ and herding activity (17.3 individual dolphins $\mathrm{SD} \pm 7.6, \mathrm{n}=12$, range $=9$ to 30 ) (Ponnampalam et al. 2013). The mean group size in the Sundarbans mangrove forest was $2.3(\mathrm{SD} \pm 1.36$, range $=$ 1-6) (Smith et al. 2006).

\section{CONCLUSION}

The current study represents the first fundamental information on the occurrence, distribution, and group size of Irrawaddy dolphins in the Bay of Brunei. Overall, 49 sightings were made during the boat surveys carried between January 2016 and April 2018. The average group size was $4.5 \pm 3.3$ (range 1 to 15 ) and there were only 13 out of the 49 groups recorded with association of mother and calf. Calf occurrence in the bay indicates that breeding is occurring. This research should be continued to monitor and develop the knowledge of the Irrawaddy dolphins in the Bay of Brunei, and to provide better understanding on population threats. Long term conservation and management plans are needed to lessen the impact of anthropogenic activities on the population. The government should implement speed limits for boats and ships, and enforce fisheries regulation to restrict the use of high-rich bycatch gears. In addition, increased local Irrawaddy dolphin awareness can be achieved through focus group discussion with local fisher communities.

\section{ACKNOWLEDGEMENTS}

This study was conducted by the Marine Endangered Species (MES) Program of the Higher Institution Centre of Excellence (HICoE), Institute of Oceanography and Environment (INOS), Universiti Malaysia Terengganu (UMT) and funded by the Chinese National Key R\&D Program of China (Grant no. 2017YFC1405100), ChinaASEAN Maritime Cooperation Fund projects titled 'Joint FIO-UMT Surveys for Marine Mammals and Sea Turtles in the Bay of Brunei, 2015-2018' (Vote No. 66904) and 'Joint Surveys for Marine Endangered Species (MES) in Malaysian Waters, 2019-2023' (Vote No. 53338). We thank the Ministry of Primary Resources and Tourism, Negara Brunei Darussalam and to the Heart of Borneo Centre, in particular, for the permission and assistance to conduct marine mammal surveys in Brunei waters. Special thanks to our colleagues at the Sakam Enterprise for their continuous support on marine mammal research in the Bay of Brunei.

\section{REFERENCES}

Atkins, S., Pillay, N. \& Peddemors, V.M. 2004. Spatial distribution of Indo-Pacific Humpback Dolphins (Sousa chinensis) at Richards Bay, South Africa: Environmental influences and behavioural patterns. Aquatic Mammals 30(1): 84-93.

Baird, I.G. \& Mounsouphom, B. 1997. Distribution, mortality, diet and conservation of Irrawaddy Dolphins (Orcaella brevirostris Gray) in Lao PDR. Asian Marine Biology 14: 41-48.

Baird, I.G. \& Mounsouphom, B. 1994. Irrawaddy dolphins in Southern Lao PDR and northeastern Cambodia. Natural History Bulletin of the Siam Society 42: 159-175.

Bali, J., Jaaman, S.A., Saleh, E., Munsang, T., Tisen, O. \& Ganyai, T. 2017. Distribution, abundance and density of Irrawaddy Dolphin (Orcaella brevirostris) in Rajang River of Sarawak, East Malaysia. Malaysian Applied Biology 46: 105-114.

Barros, N.B., Jefferson, T.A. \& Parsons, E.C.M. 2004. Feeding habits of Indo-Pacific humpback dolphins (Sousa chinensis) stranded in Hong Kong. Aquatic Mammals 30(1): 179-188.

Beasley, I., Phay, S., Lor, K.S. \& Yim, S. 2003. Mekong Dolphin Conservation Project (Unpublished report). James Cook University, Australia; Department of Fisheries, Cambodia and the Wildlife Conservation Society, Cambodia Program.

Beasley, I., Chooruk, S. \& Piwpong, N. 2002. The status of the Irrawaddy dolphin, Orcaella brevirostris, in Songkhla Lake, Southern Thailand. Raffles Bulletin of Zoology Supplement 10: 75-83.

Elkin, J. 1992. Observations of marine animals in the coastal waters of western Brunei Darussalam. Brunei Museum Journal 7: 74-87. 
Fury, C.A. \& Harrison, P.L. 2011. Impact of flood events on dolphin occupancy patterns. Marine Mammal Science 27(3): 185-205.

Gibson-Hill, C.A. 1950. The whale, porpoises and dolphins known in Sarawak waters. The Sarawak Museum Journal 5: 288-296.

Gibson-Hill, C.A. 1949. The whale, porpoises and dolphins known in Malayan waters. The Malayan Nature Journal 4: 44-61.

Hashim, N.A.N. \& Jaaman, S.A. 2011. Boat effects on the behavior of Indo-Pacific Humpback (Sousa chinensis) and Irrawaddy Dolphin (Orcaella brevirostris) in Cowie Bay, Sabah, Malaysia. Sains Malaysiana 40(12): 1383-1392.

Hines, E., Strindberg, S., Junchompoo, C., Ponnampalam, L., Ilangakoon, A., Jackson-Ricketts, J. \& Monanunsap, S. 2015. Line transect estimates of Irrawaddy dolphin abundance along the eastern Gulf Coast of Thailand. Frontiers in Marine Science. doi: 10.3389/fmars.2015.00063.

Jaaman, S.A. \& Bali, J. 2011. Marine mammals of Borneo. In Malaysia's Marine Biodiversity: Inventory and Current Status, edited by Kamarruddin, I., Mohamed, C.A.R., Rozaimi, M.J., Kee-Alfian, B.A.A., Fitra, A.Z. \& Lee, J.N. Putrajaya: Department of Marine Park Malaysia. pp. 47-69.

Jaaman, S.A., Muda, A.M., Abdul-Raman, A., Bali, J., Munsang, T.K. \& Muhamad, H.M. 2016. Surveys of marine mammals in the Bay of Brunei, Malaysia. In Scientific Expedition to Brunei Bay, edited by Suratman, S. Penerbit UMT: Universiti Malaysia Terengganu. pp. 151-174.

Jackson-Ricketts, J. 2016. Diet, life history, habitat, and conservation of Irrawaddy dolphins (Orcaella brevirostris) in the Gulf of Thailand (Doctoral dissertation) (Unpublished). https://escholarship.org/uc/item/19q2k06f.

Jefferson, T.A. 2000. Population biology of the Indo-Pacific hump-backed dolphin in Hong Kong waters. Wildlife Monographs 144: 1-65.

Jefferson, T.A. \& Hung, S.K. 2004. A review of the status of the Indo-Pacific humpback dolphins (Sousa chinensis) in Chinese Waters. Aquatic Mammals 30(1): 149-158.

Jefferson, T.A., Webber, M.A. \& Pitman, R.L. 2008. Marine Mammals of the World: A Comprehensive Guide to Their Identification. London: Academic Press. pp. 153-155.

Jiang, Y., Liu, Z., Yang, C., Lü, L., Yu, X., Huang, L., Zhang, X., Yang, Z., Yang, G., Sun, L., Jaaman, S.A. \& Muda, A.M. 2020. High-frequency whistles of Irrawaddy dolphins (Orcaella brevirostris) recorded in Brunei Bay. Marine Mammal Science 2020: 1-12. doi: 10.1111/mms. 12681.

Jiang, Y., Zhang, X., Yang, Z., Jaaman, S.A., Xu, Q., Muda, A.M. \& Muhamad, H.M. 2019. Preliminary analysis of echolocation signals produced by fleeing Irrawaddy dolphins (Orcaella brevirostris). Acta Oceanologica Sinica -English Edition- 38(1): 85. doi: 10.1007/s13131-0191373-y.

Junchompoo, C., Monanunsap, S. \& Penpein, C. 2013. Population and conservation status of Iirawaddy Dolphins (Orcaella brevirostris) in Trat Bay, Trat Province, Thailand.
Proceedings of the Design Symposium on Conservation of Ecosystem (The 13th SEASTAR2000 Workshop). doi: 10.13140/2.1.5183.3601.

Khalifa, M.A., Kamal, M.M., Adiwilaga, E.M. \& Sunuddin, A. 2014. Preliminary study on the distribution of Irrawaddy Dolphin, Orcaella brevirostris, in Banten Bay. Open Journal of Marine Science 4(4): 338-343.

Kreb, D., Budiono \& Syachraini. 2007. Status and conservation of Irrawaddy Dolphins Orcaella brevirostris in the Mahakam River of Indonesia. In Status and Conservation of Freshwater Populations of Irrawaddy Dolphins, WCS Working Paper 31, edited by Smith, B.D., Shore, R.G. \& Lopez, A. Bronx, New York: Wildlife Conservation Society. pp. 53-66.

Krützen, M., Beasley, I., Ackermann, C.Y., Lieckfeldt, D., Ludwig, A., Ryan, G.E., Bejder, L., Parra, G.J., Wolfensberger, R. \& Spencer, P. 2018. Demographic collapse and low genetic diversity of the Irrawaddy dolphin population inhabiting the Mekong River. PLoS ONE 13(1): e0189200. https://doi. org/10.1371/journal.pone.0189200.

Kuit, S.H., Ponnampalam, L., Ng, J., Chong, V. \& Then, A. 2019. Distribution and habitat characteristics of three sympatric cetacean species in the coastal waters of Matang, Perak, Peninsular Malaysia. Aquatic Conservation: Marine and Freshwater Ecosystems. https://doi.org/10.1002/aqc.3121.

Lim, P.E. 1992. Water quality in the coastal areas of Brunei Darussalam: Status, management issues and recommendations. In The Coastal Resources of Brunei Darussalam: Status, Utilization and Management, edited by Silvestre, G.T., Matdanan, H.J.H., Sharifuddin, P.H.Y., De Silva, M.W.R.N. \& Chua, T.E. ICLARM Conference. Proceeding. pp. 91-108.

Mahmud, A.I. 2016. Population estimation and behavioural patterns of Irrawaddy dolphins, Orcaella brevirostris (Owen in Gray 1866) in the Brunei Bay, Malaysia (Master's thesis, Erasmus Mundus Master Course in Tropical Biodiversity and Ecosystem).

Mahmud, A.I., Jaaman, S.A., Muda, A.M., Muhamad, H.M., Zhang, X. \& Scapini, F. 2018a. Factors influencing the behaviour of Irrawaddy dolphins Orcaella brevirostris (Owen in Gray, 1866) in Brunei Bay, Malaysia. Journal of Ethology. doi: 10.1007/s10164-018-0549-9.

Mahmud, A.I., Jaaman, S.A., Muda, A.M., Muhamad, H.M., Zhang, X. \& Scapini, F. 2018b. Population estimation, distribution, and habitat preference of Irrawaddy dolphins Orcaella brevirostris (Owen in Gray, 1866) in the Brunei Bay, Malaysian waters. Wildlife Biology 2018(1). doi: 10.2981/ wlb.00383.

Marsh, H., Lloze, R., Heinsohand, G.E. \& Kasuya, T. 1998. Irrawaddy dolphin Orcaella brevirostris (Gray, 1866). In Handbook of Marine Mammals, Vol 4, edited by Ridgway, S.H. \& Harrison, R.J. London: Academic Press. pp. 101-118.

Ministry of Industry and Primary Resources. 2015. 5th National Report to the Convention on Biological Diversity, Brunei Darussalam. https://www.cbd.int/doc/world/bn/bn-nr-05en.pdf. 
Minton, G., Smith, B.D., Braulik, G.T., Kreb, D., Sutaria, D. \& Reeves, R. 2017. Orcaella brevirostris (errata version published in 2018). The IUCN Red List of Threatened Species. http://dx.doi.org/10.2305/IUCN.UK.20173.RLTS. T15419A50367860.en.

Muhamad, H.M., Xu, X., Zhang, X., Jaaman, S.A. \& Muda, A.M. 2018. Whistle description of Irrawaddy dolphins (Orcaella brevirostris) in Bay of Brunei, Sarawak, Malaysia. The Journal of the Acoustical Society of America 143(5): 2708. https://doi.org/10.1121/1.5036926.

Muhamad, H.M., Xu, X., Zhang, X., Jaaman, S.A., Muda, A.M., Ismail, F.D. \& Azizul, N. 2020. Echolocation clicks of Irrawaddy Dolphins (Orcaella brevirostris) during foraging in the Bay of Brunei, Malaysia. Acoustics Australia 48: 201210. doi:10.1007/s40857-020-00183-5.

Owen, R. 1866. On some Indian Cetacea collected by Walter Elliot. Transactions of Zoological Society of London 6(1): 17-47.

Pattnaik, A., Sutaria, D., Khan, M. \& Behera, B.P. 2007. Status and conservation of Irrawaddy Dolphins Orcaella brevirostris in Chilika Lagoon of India. In Status and Conservation of Freshwater Populations of Irrawaddy Dolphins, edited by Smith, B.D., Shore, R.G. \& Lopez, A. WCS Working Papers 1530-4426. pp. 90-109.

Perrin, W., Dolar, M.L.L. \& Alava, M.N.R. 1996. Report of the Workshop on the Biology and Conservation of Small Cetaceans and Dugongs of Southeast Asia, Dumaguete, 27-30 June 1995. UNEP(W)EAS WG 1/2. United Nations Environment Programme, Bangkok.

Pilleri, G. \& Gihr, M. 1974. Contribution to the knowledge of the cetaceans of southwest and monsoon Asia (Persian Gulf, Indus Delta, Malabar, Andaman Sea and Gulf of Siam). Investigations on Cetacea 5: 95-149.

Ponnampalam, L., Hines, E., Monanunsap, S., Ilangakoon, A., Junchompoo, C., Adulyanukosol, K. \& Morse, L. 2013. Behavioral observations of coastal Irrawaddy dolphins (Orcaella brevirostris) in Trat Province, Eastern Gulf of Thailand. Aquatic Mammals 39(4): 401-408. doi: DOI:10.1578/AM.39.4.2013.401.

Rodríguez-Vargas, L., Rajamani, L., Dolar, L. \& Porter, L. 2019. Population size, distribution and daylight behaviour of Irrawaddy dolphins (Orcaella brevirostris) in Penang Island, Malaysia. Raffles Bulletin of Zoology 67: 671-683.

Ross, G.J.B. 2002. Humpback dolphins, Sousa chinensis, S. plumbea, and S. teuszi. In Encyclopedia of Marine Mammals, edited by Würsig, B., Perrin, W. \& Thewissen, J.G.M. San Diego: Academic Press. pp. 585-589.

Silvestre, G.T. \& Garces, L.R. 2004. Population parameters and exploitation rate of demersal fishes in Brunei Darussalam (1989-1990). Fish Research 69: 73-90.

Smith, B.D. 2004. Orcaella brevirostris (Ayeyarwady River subpopulation). 2004 IUCN Red List of Threatened Species. http://www.redlist.org/.
Smith, B.D. \& Beasley, I. 2004a. Orcaella brevirostris (Mekong River subpopulation). 2004 IUCN Red List of Threatened Species. http://www. redlist.org/.

Smith, B.D. \& Beasley, I. 2004b. Orcaella brevirostris (Songkhla Lake subpopulation). 2004 IUCN Red List of Threatened Species. http://www. redlist.org/.

Smith, B.D., Braulik, G., Strindberg, S., Ahmed, B. \& Mansur, R. 2006. Abundance of Irrawaddy dolphins (Orcaella brevirostris) and Ganges River dolphins (Plantanista gangetica gangetica) estimated using concurrent counts made by independent teams in waterways of the Sundarbans mangrove forest in Bangladesh. Marine Mammal Science 22(3): 527-547. doi: 10.1111/j.17487692.2006.00041.x.

Smith, B.D., Jefferson, T.A., Leatherwood, S., Ho, D.T., Thuoc, C.V. \& Quang, L.H. 1997. Investigation of Marine Mammals in Vietnam. Asian Marine Biology 14: 145-172.

Stacey, P.J. \& Hvenegaard, G.T. 2002. Habitat use and behavior of Irrawaddy Dolphin (Orcaella brevirostris) in the Mekong River of Laos. Aquatic Mammals 28(1): 1-13.

Stacey, P.J. \& Leatherwood, S. 1997. The Irrawaddy dolphin, Orcaella brevirostris: A summary of current knowledge and recommendations for conservation action. Asian Marine Biology 14: 195-214.

Sutaria, D. \& Marsh, H. 2011. Abundance estimates of Irrawaddy dolphins in Chilika Lagoon, India, using photo-identification based mark-recapture methods. Marine Mammal Science 27: $338-348$

Tisen, O.B. 2011. Pilot Project: Financial Incentive for Dugong Management. United Arab Emirate: UNEP.

Tubbs, S.E., Keen, E., Jones, A.L. \& Thap, R. 2020. On the distribution, behaviour and seasonal variation of Irrawaddy dolphins (Orcaella brevirostris) in the Kep Archipelago, Cambodia. Raffles Bulletin of Zoology 68: 137-149.

Wang, J.Y., Yang, S. \& Liao, H. 2001. Species composition, distribution and relative abundance of cetaceans in the waters of Southern Taiwan: Implications for conservation and eco-tourism. Journal of the National Parks of Taiwan 11(2): 136-158

Wang, X., Wu, F., Turvey, S.T., Rosso, M. \& Zhu, Q. 2016. Seasonal group characteristics and occurrence patterns of Indo-Pacific humpback dolphins (Sousa chinensis) in Xiamen Bay, Fujian Province, China. Journal of Mammalogy 97(4): 1026-1032.

Weber, M. 1923. Die Cetaceen der Siboga-Expedition. Vorkommen und Fang der Cetaceen im Indo-Australischen Archipel. Siboga-Expeditie 58. Leiden: E.J. Brill. pp. 1-38. pls I-III.

Weir, C.R. 2009. Distribution, behavior and photo-identification of Atlantic humpback dolphins Sousa teuszii off Flamingos, Angola. Journal of Marine Science 31(3): 319-331. 
Farah Dayana Haji Ismail, Nurlisa Azizul, Saifullah Arifin Jaaman* \& Azmi Marzuki Muda

Institute of Oceanography and Environment

Universiti Malaysia Terengganu

21030 Kuala Nerus, Terengganu Darul Iman

Malaysia

Mohd Vol Momin \& Bohari Abdullah

Sakam Enterprise, Unit 17C, 2nd Floor

Bgn. Ben Kassim \& Hjh Zaliha

Spg 440, Kg. Sungai Tilong

Jalan Muara BC3315

Brunei Darussalam

Xuelei Zhang

Marine Ecology Research Center

First Institute of Oceanography (FIO)

Ministry of Natural Resources

Qingdao 266061

China
Hairul Masrini Muhamad

Key Laboratory of Underwater Acoustics

\& Marine Information Technology

Department of Applied Marine Physics \& Engineering

College of Ocean and Earth, Xiamen University

China

*Corresponding author; email: saifullahaj@umt.edu.my

Received: 2 November 2019

Accepted: 11 March 2021 